\title{
O BRASIL EM SÃO JOSÉ DA COSTA RICA: 20 ANOS DE RECONHECIMENTO DA JURISDIÇÃO CONTENCIOSA DA CORTE INTERAMERICANA DE DIREITOS HUMANOS
}

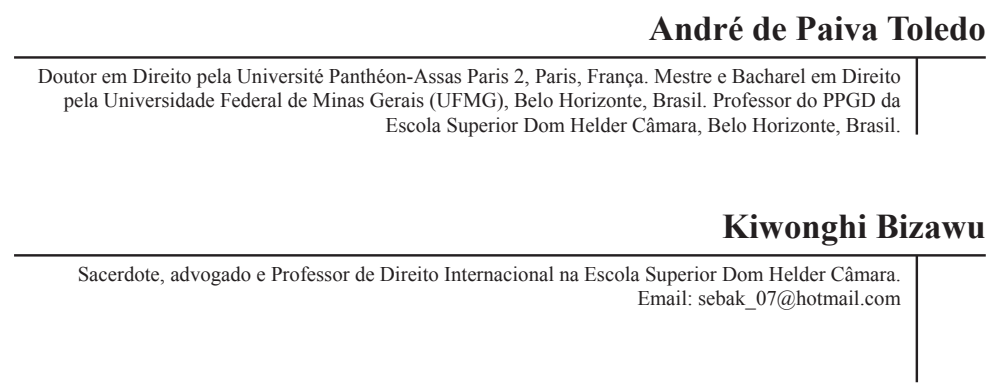

\begin{abstract}
RESUMO
Este artigo foi elaborado para marcar o $20^{\circ}$ aniversário de reconhecimento pelo Estado brasileiro da jurisdição contenciosa da Corte Interamericana de Direitos Humanos. Pretende-se fazer uma análise individualizada das sentenças em nove casos em que o Brasil foi réu entre 1998 e 2018 para, em seguida, identificar os aspectos sistêmicos, apontando as principais dificuldades para seu cumprimento. Conclui-se que as responsabilizações do Brasil concentram-se em quatro grandes eixos: violência médica, questão fundiária, violência policial e trabalho escravo. No que concerne aos obstáculos ao cumprimento das sentenças, destaca-se a insistência na aplicação interna de prescrição e anistia em relação a crimes contra a humanidade.
\end{abstract}

Palavras-chave: Corte Interamericana de Direitos Humanos; Brasil; jurisdição contenciosa. 


\title{
BRAZIL IN SAN JOSÉ, COSTA RICA: 20 YEARS OF ACKNOWLEDGEMENT OF THE CONTROVERSIAL INTER- AMERICAN COURT OF HUMAN RIGHTS
}

\begin{abstract}
This article was written to mark the $20^{\text {th }}$ anniversary of recognition by the Brazilian State of the contentious jurisdiction of the Inter-American Court of Human Rights. It is intended to make an individualized analysis of the sentences in nine cases in which Brazil was defendant between 1998 and 2018. It identifies then the systemic aspects of the sentences, pointing out the main difficulties for its compliance. It is concluded that Brazil's responsibilities are concentrated in four main areas: medical violence, land issues, police violence and slave labor. Concerning the obstacles to compliance with the judgments, the insistence on the internal application of prescription and amnesty in relation to crimes against humanity stands out.
\end{abstract}

Keywords: Inter-American Court of Human Rights; Brazil; contentious jurisdiction. 


\section{INTRODUÇÃO}

Apesar de a Convenção Americana de Direitos Humanos (CADH) ter sido adotada em 1969 e ter entrado em vigor em 1978, o Brasil só depositou a carta de adesão em 25 de setembro de 1992, uma semana antes do Massacre do Carandiru'. Desde então, o Brasil é obrigado a respeitar e assegurar o pleno exercício dos direitos ali previstos. O dever de respeito consiste em impedir que os agentes públicos violem direitos, enquanto o dever de garantia concretiza-se na adoção de todas as medidas para assegurar o gozo desses direitos. Se, ainda assim, ocorrer uma violação, o Estado deve investigar, julgar e punir os responsáveis, assim como reparar as vítimas ou seus familiares (RAMOS, 2007).

Seis anos depois da adesão à $\mathrm{CADH}$, em 10 de dezembro de 1998, o Brasil depositou nota de reconhecimento soberano da jurisdição contenciosa $^{2}$ da Corte Interamericana de Direitos Humanos (CtIDH). Desde então, pode a CtIDH julgar o mérito de casos sobre a interpretação e aplicação da CADH, que envolvam o Brasil (ROSATO; CORREIA, 2011). Quando se completam vinte anos de jurisdição contenciosa da CtIDH em relação a demandas de responsabilização do Brasil por violação de direitos humanos protegidos na $\mathrm{CADH}$, a presente pesquisa pretende, em um primeiro momento, fazer um balanço dos casos, identificando as principais características dos fatos controversos e analisando os rumos das discussões sobre o direito. Ao final, faz-se uma comparação desses elementos distintivos, apontando os grandes desafios que se põem ao País em termos de respeito à dignidade humana.

\section{JURISDIÇÃO CONTENCIOSA DA CTIDH}

À CtIDH compete examinar o mérito de casos em que são réus os Estados-partes da $\mathrm{CADH}$, que tenham, por sua vez, reconhecido expressamente sua jurisdição, como o é o Brasil, desde 1998. Excluída, por questão metodológica, a competência consultiva ${ }^{3}$, uma demanda de

1 O Massacre do Carandiru foi o resultado de uma operação da Polícia Militar de São Paulo, realizada em 2 de outubro de 1992, para conter uma rebelião de presos da Casa de Detenção de São Paulo (Carandiru), que resultou na morte 111 detentos.

2 A CtIDH pode também adotar opiniões consultivas sobre interpretação da CADH ou outro tratado americano de direitos humanos, quando solicitado por membro da Organização dos Estados Americanos (OEA). Além disso, qualquer Estado parte da CADH pode solicitar à CtIDH a opinião consultiva sobre a convencionalidade de normas de direito interno.

3 Qualquer membro da OEA pode solicitar um parecer da CtIDH sobre interpretação da CADH ou outro tratado de proteção de direitos humanos, reconhecido pelos Estados americanos. A CtIDH pode, 
responsabilização de Estado por violação da $\mathrm{CADH}$ só pode ser submetida à CtIDH por outro Estado-parte ou pela Comissão Interamericana de Direitos Humanos (CIDH), embora a primeira hipótese nunca tenha acontecido. Não há aqui, portanto, previsão normativa de legitimidade ativa dos indivíduos, como já ocorre, desde 1998, no Sistema Europeu de Direitos Humanos ${ }^{4}$. Contudo, para que a CIDH aja, é necessário que o indivíduo, um grupo de indivíduos ou organizações não governamentais, reconhecidas em um ou mais Estados-membros da OEA, apresentem-lhe uma petição com denúncia de violação por Estado-parte de direitos previsto na CADH (MICHEL; DEITOS, 2017). Recebida a petição, a CIDH examina as condições de admissibilidade, que são, em resumo, o esgotamento dos recursos internos, a ausência de litispendência internacional ou de manifestação anterior a respeito por organismo internacional, a legitimidade ativa do peticionário e a razoabilidade da demanda (BARROZO; SILVA; PALUMA, 2014). O esgotamento dos recursos internos pode ser afastado, no caso concreto, caso haja demora injustificada, ineficiência do recurso ou inexistência de normas internas de defesa dos direitos humanos (CANÇADO TRINDADE, 2002).

Verificada a admissibilidade da petição, a CIDH propõe às vítimas e ao Estado uma solução amistosa ${ }^{5}$, o que depende diretamente do consentimento dos envolvidos (BERNARDES; VENTURA, 2012). Caso não seja possível a conciliação, a CIDH passa a analisar a questão de mérito. Se se identificarem indícios de violação de direitos humanos, a CIDH recomenda, por relatório confidencial, ao Estado, a adoção de determinadas medidas de reparação ${ }^{6}$ (PIOVESAN, 2007). Se o Estado não seguir as recomendações, em regra, a CIDH deve automaticamente apresentar contra ele junto à CtIDH uma demanda de responsabilização internacional, desde que haja o reconhecimento prévio de sua jurisdição contenciosa por tal Estado, o que, em relação ao Brasil, aconteceu apenas em 1998 (RAMOS, 2007).

Proposta a ação contra o Estado-parte, por violação de dispositivo

também, exercer um controle de convencionalidade de normas de direito interno dos Estados-partes da CADH.

4 A partir da adoção do Protocolo 11 à Convenção de Salvaguarda dos Direitos Humanos e das Liberdades Fundamentais (Roma, 1950), todas as alegações de violação de direitos dos indivíduos são diretamente encaminhadas à Corte Europeia de Direitos Humanos.

5 Caso José Pereira vs. Brasil (Relatório 95/2003) e Caso Meninos emasculados do Maranhão (Relatório 95/2003).

6 Por exemplo, Caso Maria da Penha Maia Fernandes vs. Brasil (2000, Relatório 54/2001) e Caso das Comunidades Indígenas da Bacia do Rio Xingu vs. Brasil (Belo Monte, Medidas Cautelares 382/2010). 
da CADH, a CIDH torna-se parte meramente processual da ação, sendo o indivíduo, cujo direito é defendido, a verdadeira parte material (CANÇADO TRINDADE, 2002). O indivíduo pode, inclusive, segundo o Regulamento da CtIDH, indicar representantes e participar diretamente de todas as fases processuais.

Provocada pela CIDH, a CtIDH poderá reexaminar as condições de admissibilidade da ação (MICHEL; DEITOS, 2017). Confirmada esta, dá-se a oportunidade de defesa do réu, quando se apresentam as exceções preliminares e a argumentação de mérito. Em seguida, caso entenda ser interessante, a Corte pode propor uma solução de conciliação às partes. Se não houver acordo, ocorre a fase probatória e, em seguida, a fase decisória. Proferida a sentença pela CtIDH, condenado o réu, deve este cumpri-la, reparando o dano causado. A decisão tem força vinculante, cabendo ao Estado seu imediato cumprimento, o que se torna objeto de supervisão por parte da própria CtIDH (BARROZO; SILVA; PALUMA, 2014). Verificado eventualmente o descumprimento da sentença, é possível que a questão seja levada pela CtIDH à Assembleia Geral da OEA, a fim de pressionar o Estado condenado a agir (ZAVERUCHA; LEITE, 2016). Nesse contexto, a Assembleia Geral pode emitir resolução, recomendando aos membros da OEA a adoção de sanções econômicas, até o cumprimento da sentença (CEIA, 2013).

Desde 1998, contra o Brasil, houve o julgamento do mérito pela CtIDH de nove casos apresentados pela CIDH. Nesses vinte anos, o Brasil esteve em São José da Costa Rica, para defender-se das acusações de responsabilidade por violação da CADH. Apesar disso, em oito oportunidades, o País foi condenado. Para uma boa compreensão dos desafios internacionais sobre direitos humanos no Brasil, em face da jurisdição contenciosa da CtIDH, passa-se à análise dos casos individualmente para, em seguida, ser possível a identificação de um padrão geral.

\section{CASO XIMENES LOPES VS. BRASIL (2006)}

Damião Ximenes Lopes sofria de doença mental. Em $1^{\circ}$ de outubro de 1999, sua mãe internou-o no Hospital Psiquiátrico "Casa de Repouso Guararapes", localizado em Sobral/CE, estabelecimento credenciado ao Sistema Único de Saúde (SUS) (LIMA; PONTES, 2015). Três dias depois, um funcionário do hospital tentou impedir que Damião fosse visitado pela mãe, a fim de que ela não visse o estado em que ele 
se encontrava. Damião estava com as mãos amarradas nas costas e muito machucado. Irreconhecível por conta dos ferimentos, ele fedia a excremento e urina. Enquanto a mãe discutia com o único médico de plantão, Francisco Ivo de Vasconcelos, Damião foi levado ao banho por enfermeiros. O tratamento recebido, entretanto, não foi suficiente para impedir sua morte, dentro do hospital, duas horas depois (ROSATO; CORREIA, 2011). A necropsia revelou que Damião havia sofrido diversos golpes, apresentando escoriações localizadas na região nasal, ombro direito, parte anterior dos joelhos e do pé esquerdo, equimoses localizadas na região do olho esquerdo, ombro homolateral e punho (RAMOS, 2007).

A família de Damião passou, então, a lutar para que os responsáveis pela morte fossem punidos criminalmente e que houvesse o pagamento de indenização por danos materiais e morais. Entretanto, nenhuma medida foi tomada pela polícia. Procurado o Ministério Público do Ceará, interpuseram-se ações criminal e cível de indenização, sem que tenha havido decisão em tempo razoável (RAMOS, 2006).

Diante da omissão do Brasil, em 1999, a família e uma organização não governamental apresentaram uma petição sobre o caso à CIDH (LIMA; PONTES, 2015), que iniciou imediatamente o exame da questão, concluindo, em 2002, que a petição satisfazia os requisitos de admissibilidade. Feita uma análise de mérito em relação aos padrões médicos a serem adotados com doentes mentais, a CIDH concluiu, em 2003, que o Brasil havia violado, naquele caso, obrigações internacionais de direitos humanos (ROSATO; CORREIA, 2011). Diante disso, a CIDH recomendou ao Brasil a realização de uma investigação completa, imparcial e efetiva dos fatos relacionados com a morte de Damião e uma reparação adequada a seus familiares, incluindo aí o pagamento de indenização. Contudo, o Brasil não acatou integralmente essas recomendações. Em virtude disso, a CIDH decidiu submeter o caso à CtIDH, indicando que o Brasil violara o dever geral de respeitar e garantir os direitos ${ }^{7}$ previstos na $\mathrm{CADH}$ e, especificamente, os direitos à vida, integridade pessoal, proteção judicial e garantias judiciais ${ }^{8}$, em razão das condições inumanas e degradantes da hospitalização de Damião e da falta de investigação e de fornecimento à família de recurso efetivo à defesa de direitos (CtIDH, 2006a).

Como preliminar, o Brasil alegou a falta do esgotamento dos

7 Artigo 1.1 da CADH.

8 Artigos 4, 5, 8 e 25 da CADH. 
recursos internos ${ }^{9}$, tendo em vista que a ação de responsabilização, no âmbito interno, ainda estava em curso. Contudo, a CtIDH afastou essa preliminar porque o Brasil havia tacitamente renunciado a ela quando não a suscitou junto à $\mathrm{CIDH}^{10}$. Em 2006, durante a audiência, o Estado brasileiro reconheceu sua responsabilidade internacional pela violação do direito à vida e à integridade física, mas, rechaçou-a frente às denúncias relativas à falta de proteção judicial e garantias judiciais. Do mesmo modo, negou-se a reconhecer a violação do direito à integridade psíquica dos familiares de Damião, o que impedia o pagamento de qualquer indenização (CtIDH, 2006a).

Em sua sentença, a CtIDH examinou, pela primeira vez, os direitos de pessoa com doença mental. Foi a primeira vez, também, que o Brasil foi condenado em um julgamento de mérito. Na sentença, reconheceu-se a responsabilidade do País por ato de particular sob a supervisão e fiscalização do Poder Público. Além disso, ficou claro para a CtIDH que as pessoas com deficiência, por sua vulnerabilidade, exigem do Estado maior cuidado e a promoção individualizada de direitos. Por conta disso, aplicou-se ao caso a Convenção Interamericana dos Direitos das Pessoas Portadoras de Deficiência (CIDPPD ${ }^{11}$ ) como vetor de interpretação da própria CADH. A CtIDH enfatizou que a doença mental não impede a autodeterminação, devendo ser presumida a capacidade das pessoas que a sofrem de expressarem sua vontade, inclusive no que concerne à recusa de tratamento, o que deve ser sempre respeitado por médicos e (outras) autoridades. Se for impossível a obtenção do consentimento dessas pessoas, seus representantes legais devem decidir o que for melhor. $\mathrm{O}$ tratamento forçado só se justifica em situação de dano iminente ou urgência, o que não ocorreu com Damião (CtIDH, 2006a).

A CtIDH também reconheceu que o sofrimento dos familiares de Damião constitui em si violação ao direito à integridade psíquica. Logo, os familiares de vítimas de violações de direitos humanos podem ser também vítimas de violações de direitos humanos. Quanto à demora na adoção de medidas internas de responsabilização e reparação, a CtIDH concluiu que as características do fato não tornavam sua apuração complexa, sendo a negligência das autoridades judiciais brasileiras a única razão da falta, o que violava o princípio da duração razoável do processo (SCHENK, 2013).

9 Artigo 61.2 da CADH.

10 Artigo 46.1(a) da CADH.

11 A CIDPPD entrou em vigor, para o Brasil, em 14 de setembro de 2001. 
As vítimas de violações de direitos humanos e seus familiares têm o direito à verdade e à justiça por meio da investigação e punição dos violadores dos direitos humanos (NUNES, 2017). O Brasil, que já havia confessado a violação dos direitos à vida e à integridade física, foi responsabilizado, também, por violação dos direitos à proteção judicial e às garantias judiciais. A CtIDH condenou, assim, o Brasil a: a) pagar indenização à família de Damião; b) investigar e identificar, em prazo razoável, os culpados de sua morte; c) promover programas de formação e capacitação de profissionais da saúde, especialmente médicos, psicólogos e enfermeiros, que lidem com pessoas com doença mental. (RAMOS, 2007)

\section{CASO NOGUEIRA DE CARVALHO E OUTRO VS. BRASIL (2006)}

O advogado Gilson Nogueira de Carvalho foi assassinado em 20 de outubro 1996, em Macaíba/RN, após divulgar os crimes cometidos por um grupo de extermínio conhecido como "Meninos de Ouro", do qual fariam parte policiais civis. Diante da falta de diligência devida do Brasil em investigar, processar e punir os assassinos, em 1997, organizações não governamentais enviaram petição à $\mathrm{CIDH}$, acusando o Estado de violar o direito da família a garantias judiciais ${ }^{12}$ (CtIDH, 2006b).

Apenas em 2000, o Brasil alegou que havia realizado investigações sobre a morte de Gilson, tendo o Ministério Público do Rio Grande do Norte apresentado a ação penal respectiva ${ }^{13}$. Depois disso, o Brasil não mais se manifestou, o que foi interpretado pela CIDH como concordância com o alegado pelos peticionários e como desinteresse por uma solução conciliatória (RAMOS, 2007).

Em 2005, a CIDH interpôs ação de responsabilização internacional do Brasil junto à CtIDH. Seus argumentos consistiam no descumprimento pelo Estado do dever de respeitar os direitos humanos ${ }^{14}$ e dos direitos a garantias judiciais ${ }^{15}$ e proteção judicial de Jaurídice Nogueira de Carvalho e Geraldo Cruz de Carvalho, pais de Gilson, por falta de diligência devida na responsabilização dos autores do homicídio (LIMA, 2010).

\footnotetext{
12 Artigo 25 da CADH.

13 Em 2004, o réu desta ação penal foi absolvido pelo Tribunal do Júri por falta de provas (BARROZO; SILVA; PALUMA, 2014).

14 Artigo 1.1 da CADH.

15 Artigo 8 da CADH.
} 
Neste caso, o Brasil testou o alcance da cláusula temporal ${ }^{16}$. Como o assassinato de Gilson ocorreu em 1996, dois anos antes do reconhecimento da jurisdição contenciosa, o Brasil alegou ser a CtIDH incompetente ratione temporis para julgar o caso. A CtIDH reconheceu que não podia conhecer da morte de Gilson, mas que era competente para analisar as violações permanentes, decorrentes daquele fato anterior, como é o caso da denegação de justiça aos pais de Gilson. O Brasil alegou, também, a falta de esgotamento dos recursos internos. Como acontecera no caso de Damião, a CtIDH observou que o Brasil não poderia levantar essa exceção, pois não o havia feito junto à CIDH. Sobre o mérito, o Brasil afirmou que realizou investigação séria e imparcial, mas que a complexidade do caso impediu-o de responsabilizar o assassino de Gilson. A ausência de condenação penal não significaria violação ao devido processo legal, quando o Estado se empenha em elucidar o fato. O dever de punir é obrigação de meio e não de resultado (LIMA, 2010).

A CtIDH sustentou que não lhe cabia substituir a jurisdição interna, fixando as modalidades específicas de investigação e julgamento, cabendo-lhe apenas constatar se, no âmbito interno, foram ou não violadas as obrigações de proteção judicial e garantias judiciais. Diante das provas apresentadas, a CtIDH concluiu inexistir prova de que o Brasil havia violado tais direitos, o que motivou-a, por unanimidade, a indeferir a demanda, absolver o Estado e arquivar o caso (CtIDH, 2006b).

\section{CASO ESCHER E OUTROS VS. BRASIL (2009)}

Em 3 de maio de 1999, o major da Polícia Militar do Paraná (PMPR), Waldir Copetti Neves, solicitou à juíza da Comarca de Loanda/ PR, Elisabeth Kather, que autorizasse a empresa de telecomunicações do Paraná a realizar a interceptação e monitoramento da linha telefônica da Cooperativa Agrícola de Conciliação Avante Ltda. (COANA), sediada em Querência do Norte/PR, a fim de investigar delitos supostamente ligados a seus diretores, Arley José Escher, Dalton Luciano de Vargas, Delino José Becker, Pedro Alves Cabral, Celso Aghinoni e Eduardo Aghinoni. Porém, deferiu-se o pedido sem dar notícia disso ao Ministério Público do Paraná (MPPR). Além da linha telefônica da COANA, sem autorização judicial, realizaram-se também a interceptação e monitoramento do telefone da Associação Comunitária de Trabalhadores Rurais (ADECON).

16 Artigo 62.2 da CADH. 
A COANA e a ADECON eram vinculadas diretamente ao Movimento dos Trabalhadores Rurais Sem Terra (MST). Em 8 de junho de 1999, trechos das interceptações foram reproduzidos no Jornal Nacional da Rede Globo e em diversos órgãos da imprensa local.

Em 2000, o MPPR concluiu que as interceptações telefônicas haviam sido realizadas em violação do direito à intimidade, vida privada $\mathrm{e}$ livre associação. Na mesma época, impetrou-se um mandado de segurança contra a decisão do juízo de Loanda, que havia autorizado a interceptação telefônica. O pedido foi indeferido por falta de objeto, uma vez que o grampo telefônico havia sido encerrado. Contra essa decisão, apresentaramse embargos de declaração para que as gravações fossem destruídas, o que também foi rejeitado. Assim como se rejeitou a denúncia apresentada pelo MPPR contra a juíza, os comandantes da PMPR e um terceiro-sargento da PMPR (CtIDH, 2009a).

Face a esses insucessos, uma petição foi enviada por organizações não governamentais à $\mathrm{CIDH}$, em 2000, denunciando a violação do direito à privacidade ${ }^{17}$ das vítimas, liberdade de associação ${ }^{18}$, garantias judiciais, proteção judicial e o descumprimento do dever de reparar os danos causados, por conta da interceptação ilegal de conversas telefônicas amplamente divulgadas e da falta de destruição do material. A CIDH recomendou ao Brasil responsabilizar os agentes e reparar as vítimas, o que não foi feito, fato que possibilitou a interposição da demanda junto à CtIDH (OLIVEIRA, 2013).

$\mathrm{Na} \mathrm{CtIDH}$, o Brasil levantou a exceção de falta de esgotamento dos recursos internos e arguiu a inexistência de condutas reprováveis a serem imputadas ao Estado. Ademais, requereu fosse reconhecida sua devida diligência quanto à investigação das denúncias, afirmando que as pretensas vítimas tiveram à disposição todos os mecanismos adequados de reparação. Especificamente sobre as interceptações, o Brasil afirmou ter cumprido o princípio da legalidade, o que afastaria a possibilidade de ofensa à honra. Por último, questionou a possibilidade de ser revista, em âmbito internacional, a conduta de agentes já examinada internamente.

Em 2009, a CtIDH afastou as preliminares levantas. No mérito, a CtIDH afirmou que as conversas telefônicas devem ser feitas com zelo, no estrito cumprimento dos limites legais, o que não aconteceu, no caso. De fato, a quebra do sigilo telefônico das vítimas dera-se em desobediência 
ao disposto na Lei 9.296/1996 ${ }^{19}$, isto é, sem a devida diligência exigida do Estado. Por conta disso, as interceptações corresponderam à violação do direito à vida privada, honra e reputação das vítimas (CtIDH, 2009a).

Além disso, a CtIDH estabeleceu que a divulgação clandestina das conversas afetou a imagem das entidades de trabalhadores rurais, o que configurava violação do direito à liberdade de associação. Por não ter sido assegurado o sigilo das gravações, praticou-se o crime do artigo 10 da Lei 9.296/1996, que não foi apurado pelo Brasil, significando, por conseguinte, violação do direito a garantias e proteção judiciais. Por unanimidade, a CtIDH condenou o Brasil a: a) pagar indenização por danos morais; b) publicar a sentença em diversos órgãos da imprensa nacional e paranaense; c) investigar, julgar e punir os responsáveis pelas violações (PIOVESAN; QUETES; FERRAZ, 2018).

\section{CASO GARIBALDI VS. BRASIL (2009)}

Trata-se de um caso relacionado diretamente com o caso anterior, pois diz respeito à violência no campo, ocorrida em Querência do Norte/ PR, município da comarca de Loanda, onde estava sediada a COANA (LEMES; CEOLIN, 2017). Em 27 de novembro de 1998, um grupo de vinte pistoleiros organizou o despejo clandestino de cerca de cinquenta famílias do MST, que ocupavam uma fazenda. Portando armas de grosso calibre, eles chegaram ao acampamento, identificando-se como policiais. Em seguida, obrigaram os moradores a deixarem suas barracas e a deitarem de bruços no chão. Quando saía de sua moradia, Sétimo Garibaldi foi baleado por um dos pistoleiros, falecendo no local. Com a morte de Sétimo, o grupo abandonou o acampamento, não concluindo o despejo clandestino.

Como sempre acontece, a polícia foi chamada, instaurando-se o respectivo inquérito, que foi, entretanto, arquivado por ordem do juízo de Loanda, em 2004. Contra essa decisão, a viúva de Sétimo impetrou um mandado de segurança, solicitando a reabertura da investigação, o que foi indeferido pelo Tribunal de Justiça do Paraná (PIOVESAN; QUETES; FERRAZ, 2018). Em 2003, apresentou-se a petição à CIDH. Os peticionários alegavam que o Brasil, por morosidade e falta de diligência devida, era internacionalmente responsável pela violação da obrigação de investigar, julgar e punir o assassino de Sétimo.

Em 2007, a CIDH interpôs a ação junto à CtIDH contra o Brasil,

19 Lei que regulamenta o artigo $5^{\circ}$, XII da Constituição brasileira. 
que se defendeu alegando preliminarmente a falta de esgotamento dos recursos internos e a incompetência ratione temporis, tendo em vista ter a morte ocorrido 13 dias antes do depósito do ato de reconhecimento da jurisdição contenciosa da CtIDH. Mais uma vez, a CtIDH reconheceu sua incompetência para conhecer do homicídio de Sétimo, mas afirmou ser permanente a violação das garantias judiciais e da proteção judicial de seus familiares. Em seguida, a CtIDH reconheceu ter havido o esgotamento dos recursos internos, pois o inquérito policial estava arquivado por ordem judicial a pedido do MPPR (CtIDH, 2009b).

No mérito, a CtIDH concluiu que o Estado não agiu com a devida diligência, quando da realização do inquérito, pois houve falta de testemunhos indispensáveis, desinteresse em esclarecer as contradições, perda de provas, descumprimento de diligências, erro no arquivamento do inquérito e demora na conclusão da investigação (GARCIA, 2016). Por conta disso, na sentença, a CtIDH concluiu que o Brasil violara o direito dos familiares de Sétimo em conhecer a verdade dos fatos. Condenou-se, assim, o Estado, a indenizar, publicar a sentença em órgãos de imprensa nacionais e paranaenses, e apurar as responsabilidades dos agentes públicos envolvidos no crime (CEIA, 2013).

\section{CASO DA GUERRILHA DO ARAGUAIA (2010)}

Desferido o Golpe de Estado contra o governo do Presidente João Goulart, em 1964, instaura-se no Brasil a ditadura, contra a qual posiciona-se o Partido Comunista do Brasil (PCdoB). Em 1969, o PCdoB resolve iniciar um movimento de resistência armada ao governo ditatorial, organizando, no Bico do Papagaio, ponto onde se encontram Pará, Tocantins e Maranhão, a Guerrilha do Araguaia. O objetivo do movimento era derrubar, pela força, a ditadura (MORAIS; SILVA, 2005).

Como reação à iniciativa revolucionária ${ }^{20}$ do $\mathrm{PCdoB}$, o governo ditatorial brasileiro pôs suas Forças Armadas para realizarem, entre $1972 \mathrm{e}$ 1975, diversas operações militares na região do Araguaia, com o intuito de exterminar os guerrilheiros. Durante a execução das operações, os militares praticaram detenções arbitrárias, tortura e desaparecimento forçado de dezenas de pessoas. Esses fatos nunca foram objeto de investigação e responsabilização por parte do Brasil (JUSTAMAND; MECHI, 2014).

20 Considera-se revolucionária toda iniciativa de derrubada de um governo antidemocrático, como o foi o governo brasileiro entre 1964 e 1989, enquanto é golpista toda iniciativa de derrubada de um governo democrático. 
Em 1982, familiares dos guerrilheiros interpuseram, no âmbito interno, uma ação ordinária de reconhecimento pelo Estado das operações de extermínio no Araguaia. Apesar disso, nunca houve qualquer resposta oficial do Brasil sobre o destino das pessoas associadas à Guerrilha do Araguaia, o que motivou os familiares e organizações não governamentais a submeterem à CIDH uma petição denunciando os fatos, antes do reconhecimento da jurisdição contenciosa da CtIDH pelo Estado (GRABOIS, 2018).

Em 2008, a CIDH constatou que, devido em grande medida à Lei de Anistia, o Brasil não realizara qualquer investigação para julgar e punir os responsáveis pelos crimes praticados, quando do enfrentamento da Guerrilha do Araguaia. Além disso, verificou-se a ineficácia dos recursos judiciais disponibilizados à família das vítimas para assegurar o direito à verdade. Onze anos após o reconhecimento da jurisdição contenciosa pelo Brasil, a CIDH decidiu encaminhar o caso da Guerrilha do Araguaia à CtIDH. Pedia-se a responsabilização do Brasil pela detenção arbitrária' ${ }^{21}$, tortura $^{22}$ e desaparecimento forçado ${ }^{23}$ de 70 pessoas, membros do $\mathrm{PCdoB}$ e camponeses, e pela execução extrajudicial ${ }^{24}$ de Maria Lúcia Petit da Silva, cujos restos mortais foram encontrados e identificados em 1996. Além disso, o Brasil deveria ser responsabilizado por falta do dever de investigar, julgar e punir $^{25}$ os responsáveis por essas violações.

Preliminarmente, como já havia acontecido em casos anteriores, o Estado levantou a falta de esgotamento dos recursos internos, pois estavam em curso, internamente, cinco ações judiciais sobre a Guerrilha do Araguaia, e a exceção de incompetência ratione temporis da CtIDH, pois os fatos alegados teriam ocorrido antes de 1998. Como resposta, a CtIDH declarou-se competente para julgar o caso, pois tais violações têm efeitos permanentes. Sobre a outra preliminar, entendeu-se que a demora em exercer a jurisdição correspondia, na prática, ao esgotamento dos recursos internos.

No mérito, o Brasil sustentou que, em virtude do disposto na Lei 9.140/1995 e no relatório "Direito à Memória e à Verdade", houve o reconhecimento da responsabilidade do Estado pelas atrocidades cometidas contra pessoas ligadas à Guerrilha do Araguaia, o que tornava sem objeto

21 Artigos 7 e 13 da CADH.

22 Artigo 5 da CADH.

23 Artigo 3 e 4 da CADH.

24 Artigo 4 da CADH.

25 Artigos 8 e 25 da CADH.

Veredas do Direito, Belo Horizonte, $\cdot$ v.15 $\cdot$ n.33 $\cdot$ p.13-50 $\cdot$ Setembro/Dezembro de 2018 
a ação junto à CtIDH. Diante disso, a CtIDH concluiu não ser objeto de controvérsia a ocorrência dos fatos e a consequente responsabilidade do Brasil. Logo, o Estado deve agir com diligência devida para investigar, julgar e punir os autores desses fatos incontroversos, apesar da Lei da Anistia, que carece de efeitos jurídicos em face da natureza de jus cogens daquelas obrigações ${ }^{26}$. Como o desaparecimento forçado implica, quase sempre, a tortura, a execução e a ocultação do cadáver, o Brasil é obrigado a garantir à família do desaparecido recursos céleres e eficazes para a localização, identificação e entrega dos restos mortais. Destaca-se, também, a ordem da CtIDH para que o Estado implemente programa ou curso permanente e obrigatório sobre direitos humanos a todos os níveis hierárquicos das Forças Armadas (CtIDH, 2010).

\section{CASO TRABALHADORES DA FAZENDA BRASIL VERDE VS. BRASIL (2016)}

Fazenda Brasil Verde é como se chama um imóvel rural, localizado em Sapucaia/PA, correspondendo a uma área total de 8.544 hectares. Em 1988, a Polícia Federal (PF) recebeu denúncia de existência de trabalho escravo naquela propriedade, assim como do desaparecimento de dois jovens trabalhadores, Iron Canuto da Silva e Luís Ferreira da Cruz (ROCHA, 2016).

Recebida a denúncia, a PF dirigiu-se à Fazenda Brasil Verde seis meses mais tarde, no início de 1989. Lá, identificou-se um sistema fraudulento de aliciamento de pessoas para trabalho temporário. Os trabalhadores eram submetidos à servidão por dívidas, caracterizada pelo desconto em salário dos gastos com comida, moradia, ferramentas, medicamentos etc. Efetivamente, os trabalhadores não recebiam salário. Nesse contexto, a única a escapatória era a arriscada fuga pela floresta. Apesar da flagrante ilicitude, a PF não realizou o inquérito policial. Em 1992, a Comissão Pastoral da Terra (CPT) denunciou a existência de escravidão na Fazenda Brasil Verde. De volta ao local, a PF identificou diversas violações ao direito trabalhista, mas isso não correspondeu a qualquer responsabilização. Anos depois, doze trabalhadores conseguiram fugir da fazenda, o que motivou, em 1997, a realização de outra operação de fiscalização, quando, enfim, o Ministério Público Federal (MPF) apresentou

26 Constatação que exige do Brasil a adequação de seu direito interno, isto é, a revogação da Lei da Anistia, nos termos do artigo 2 da CADH. 
denúncia ao juízo criminal contra o aliciador, o gerente e o proprietário da fazenda. Dois anos depois, a ação penal contra o proprietário foi suspensa. No que concerne aos dois outros acusados, diante das infinitas indefinições sobre a competência, ocorreu a prescrição punitiva. Em 2000, houve uma quarta operação de fiscalização na Fazenda Brasil Verde, quando foram identificadas as mesmas violações contra os direitos dos trabalhadores. Entre 1989 e 2002, mais de 300 trabalhadores foram resgatados da fazenda (CtIDH, 2016).

Diante da evidente falta de vontade do Estado em investigar, processar e punir a prática de trabalho escravo e o desaparecimento de Iron e Luís, apresentou-se uma petição à CIDH. Em 2007, o Brasil defendeu-se, afirmando que a demanda era inadmissível, em virtude da falta de esgotamento dos recursos internos. No mérito, alegou não poder ser internacionalmente responsável por ato de particulares. Disse também o Estado que não tinha sido omisso, uma vez que estavam sendo implementadas medidas de reforma agrária e combate à violência nas áreas rurais, além de ações de combate ao trabalho escravo. Especificamente, em relação aos fatos ocorridos na Fazenda Brasil Verde, o Brasil informou que todas as denúncias foram devidamente investigadas, mas que inexistia a obrigação de punir, senão a de investigar. As investigações tinham sido realizadas com seriedade, mas resultaram infrutíferas (DUARTE, 2017).

A CIDH considerou que a ineficiência dos recursos internos corresponde à presunção de seu esgotamento. No mérito, considerou que os trabalhadores eram tratados como bens de propriedade, o que configura a escravidão. Visto ter o Estado presenciado sem oposição as violações de direitos humanos por particulares, existia a responsabilidade do Brasil por falta de diligência devida, o que o obrigava a investigar, julgar e punir os autores de tais atos. Ademais, o Brasil também era obrigado a localizar as pessoas desaparecidas. Diante da inércia do Brasil em seguir o determinado, a CIDH interpôs junto à CtIDH a ação de responsabilização internacional.

$\mathrm{Na}$ CtIDH, o Brasil levantou a exceção de incompetência ratione personae em relação a pessoas cuja identificação não existia ou cuja vinculação com a fazenda era insuficiente. O Estado também questionou a competência ratione temporis, tendo em vista que os fatos ocorreram antes de 1998. Houve também questionamento acerca da falta de esgotamento dos recursos internos e da prescrição dos pedidos de reparação. No mérito, o Brasil defendeu-se, argumentando que a CtIDH não pode julgar casos sobre proibição do tráfico de pessoas e direitos trabalhistas, pois não estão 
previstos na CADH. Além disso, os fatos haviam sido praticados por particular. Contudo, o Brasil reconheceu que os trabalhadores resgatados encontravam-se em condições degradantes de trabalho, mas que isso não configuraria o trabalho escravo, nos termos da Convenção relativa à Escravatura $^{27}$ (DUARTE, 2017).

A CtIDH afirmou que a impossibilidade de identificação das vítimas decorria da negligência do Estado em investigar os fatos, não sendo possível alegar a própria torpeza como defesa. No que concerne à competência temporal, a CtIDH admitiu poder examinar os fatos decorrentes das fiscalizações de 1997 e 2000 na Fazenda Brasil Verde, salvo em relação ao desaparecimento de Iron e Luís, que é violação continuada. Sobre a falta de esgotamento dos recursos internos, a CtIDH não identificou quais medidas internas estariam pendentes de execução (ROCHA, 2016).

$\mathrm{Na}$ sentença, procurou-se integrar os conceitos de escravidão, servidão e trabalho forçado, previstos no artigo 6 da CADH. Primeiramente, relembrou-se que a exploração do trabalho escravo é crime contra a humanidade e, consequentemente, sua existência é contrária à norma de jus cogens. Em sequência, definiu-se que a servidão é um mecanismo análogo à escravidão, pois há o controle do trabalhador por coação física ou psicológica, sendo, assim, uma violação do direito imperativo de direito internacional geral ${ }^{28}$, que torna inadmissível a prescrição da pretensão punitiva do Estado. Nesse sentido, a CtIDH identificou omissões graves dos órgãos estatais para dar uma solução adequada ao drama daquelas pessoas, o que se reflete na duração excessiva das ações pertinentes, correspondendo ao descumprimento do dever de garantias judiciais e proteção judicial (PIOVESAN; QUETES; FERRAZ, 2018).

As violações de jus cogens eram agravadas pela vulnerabilidade socioeconômica das vítimas, isoladas na Amazônia. Por isso, o Brasil foi responsabilizado pela CtIDH por violar o direito dos trabalhadores, identificados nas fiscalizações posteriores a 1998, como não sendo submetidos ao tráfico de escravos e à escravidão (BASTOS JR; CUNHA, 2017). Ao final, além do pagamento de indenização às vítimas, a CtIDH condenou o Brasil a adequar seu direito interno ${ }^{29}$ relativo à imprescritibilidade da escravidão em todas as suas formas, tendo em vista

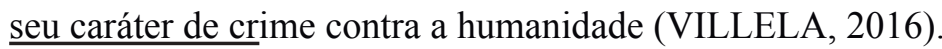

27 A Convenção relativa à Escravatura, adotada em Genebra, em 1926, e emendada pelo Protocolo de 1953, entrou em vigor, para o Brasil, em 6 de janeiro de 1966.

28 Artigo 53 da Convenção de Viena sobre o Direito dos Tratados, em vigor, para o Brasil, desde 25 de setembro de 2009.

29 Artigo 2 da CADH. 


\section{CASO DA FAVELA NOVA BRASÍLIA (2017)}

No fim da madrugada de 18 de outubro 1994, policiais civis realizaram uma incursão na Favela Nova Brasília, que faz parte do Complexo de favelas do Alemão, na cidade do Rio de Janeiro. Um grupo de 110 policiais civis, do qual participava "Turco" $"$, dirigiu-se à comunidade para, supostamente, cumprir 104 mandados de prisão contra traficantes de drogas. Porém, a imprensa noticiou que se tratava, na verdade, de uma represália ao ataque sofrido na $21^{\mathrm{a}}$ Delegacia de Polícia, três dias antes, quando três policiais ficaram feridos.

$\mathrm{Na}$ favela, os policiais invadiram, no mínimo, cinco casas. Na primeira, uma jovem de 16 anos foi torturada e abusada sexualmente, enquanto the interrogavam sobre o paradeiro de um dos líderes locais do tráfico de drogas. Nas segunda e terceira casas, houve execução sumária de, no mínimo, seis pessoas. Na quarta, os policiais detiveram arbitrariamente três indivíduos, cujos corpos apareceram entre os treze cadáveres removidos da cena do crime e abandonados em uma das ruas da favela. Na quinta casa, em que os policiais entraram atirando, havia duas jovens, de 15 e 19 anos. Uma delas foi abusada sexualmente pelos policiais. Ao final, três mulheres foram vítimas de violência sexual, nove adultos do sexo masculino foram assassinados e quatro crianças do sexo masculino foram assassinadas.

Meses depois, no início da manhã de 8 de maio de 1995, organizou-se nova incursão policial na Favela Nova Brasília. Um grupo de 14 policiais civis da Delegacia de Repressão a Roubos e Furtos contra Estabelecimentos Financeiros (DRRFCEF), com o apoio de helicópteros, tinha o objetivo de apreender um carregamento de armas, destinado a traficantes de drogas. Quando da chegada dos policiais à favela, houve intensa troca de tiros com traficantes, o que provocou pânico na comunidade. Cessado o tiroteio, constatou-se a morte de oito supostos traficantes de drogas, que haviam sido executados pelos policiais, após rendição, no imóvel de número 26 da Rua Santa Catarina. Ao final da segunda operação policial, treze pessoas do sexo masculino haviam sido mortas, sendo dois menores de idade (CtIDH, 2017).

Como resultado de ambas as incursões policiais, iniciou-se uma investigação no âmbito da Polícia Civil do Rio de Janeiro (PCRJ) e criou-se, no âmbito do Governo de Estado, uma Comissão de Investigação

30 "Turco" foi citado por sua especial truculência com as vítimas. 
Especial. Durante as investigações, as mortes foram registradas em "autos de resistência à prisão". Em face da declaração oficial de morte seguida à resistência à prisão, ambas as investigações foram arquivadas e o caso foi encerrado. Devido à omissão das autoridades brasileiras em investigar, julgar e punir os responsáveis, apresentaram-se duas ${ }^{31}$ petições à CIDH, uma para cada chacina, em 1995 e 1996, alegando-se que o Brasil era responsável pelas execuções extrajudiciais e abusos (MENEZES, 2017).

A CIDH concluiu que o Brasil era responsável por violar dispositivos da $\mathrm{CADH}$, da Convenção Interamericana para Prevenir e Punir a Tortura (CIPPT ${ }^{32}$ ) e da Convenção Interamericana para Prevenir, Punir e Erradicar a Violência contra a Mulher (Convenção de Belém do Pará ${ }^{33}$ ). Em casos relacionados a mortes causadas pela polícia, observa-se um padrão de investigação que legitima toda ação policial, o que inviabiliza seu controle, especialmente em face de grupos humanos vulneráveis. De fato, os procedimentos investigativos são tão frágeis que o uso da força policial é sempre adequado, lícito e justo. É padrão da polícia, por exemplo, não preservar o local do crime, o que inviabiliza uma perícia séria. Sobre as chacinas da Favela Nova Brasília, a CIDH recomendou ao Brasil investigar, julgar, punir os responsáveis e reparar as vítimas, inclusive seus familiares. Além disso, o Estado deveria adotar um programa mais adequado de formação de agentes de segurança pública, assim como extinguir a figura dos "autos de resistência" (MENEZES, 2017).

Diante da inércia do Estado quanto às recomendações, a CIDH interpôs, em 2015, a ação de responsabilização internacional junto à CtIDH. Em sua defesa, o Brasil levantou exceções preliminares sobre a identificação das pretensas vítimas e a cláusula temporal. A CtIDH aceitou parcialmente a exceção sobre a incompetência ratione personae, considerando como supostas vítimas apenas as pessoas identificadas no relatório da CIDH. No que concerne à incompetência ratione temporis, a CtIDH reconheceu que o Brasil vincula-se à jurisdição compulsória desde 1998, mas que isso não a impedia de julgar o caso porque se trata de violação continuada da obrigação de investigar, julgar, punir e reparar os danos causados às pessoas da Favela Nova Brasília (SILVA; MONT’ALVERNE, 2017).

No mérito, o Brasil alegou que as duas incursões policiais não

31 A CIDH só decidiu reuni-los em 2007, uma vez que se verificou que ambos versam sobre fatos similares e conexos.

32 O Brasil ratificou a CIPPT em 20 de julho de 1989.

33 O Brasil depositou a carta de ratificação da Convenção de Belém do Pará em 27 de novembro de 1995. 
foram "operações de extermínio", mas operações de segurança pública que seguiram rigorosamente o princípio da legalidade. O Estado sustentou que inexistia o menor indício de ocorrência de execução extrajudicial. Ao contrário, todos os depoimentos confirmavam que houve tiroteio entre policiais e traficantes. Sendo assim, as mortes eram consequência do exercício do direito de legítima defesa pelos policiais. Segundo o Brasil, a única falha da operação tinha sido não manter incólume a cena do crime, mas isso só aconteceu porque os policiais prestaram socorro às vítimas, transportando-as ao hospital (CELA; SILVA, 2017).

$\mathrm{Na}$ sentença, a CtIDH considerou que a investigação sobre morte decorrente de ação policial não pode ser realizada por órgão vinculado aos envolvidos, como aconteceu no caso em pauta, o que compromete a garantia de independência e imparcialidade. Além disso, as investigações não seguiram os mínimos padrões de devida diligência em casos de execuções extrajudiciais e graves violações de direitos humanos, especialmente no que se refere à duração razoável. As vítimas de violência sexual participaram apenas como testemunhas de outros fatos e não como vítimas de violação a dispositivos da CADH, CIPPT e Convenção de Belém do Pará. Todas essas faltas correspondem, consequentemente, à violação do dever de garantias judiciais e proteção judicial. Logo, cabia ao Estado retomar as investigações, tendo em vista ser inadmissível a prescrição para crimes de tortura e execuções extrajudiciais (BASTOS JR; CUNHA, 2017). A falta de diligencia devida do Brasil foi também causa de sofrimento e angústia de alguns familiares das pessoas assassinadas, que foram tratadas pela $\mathrm{CtIDH}$ como vítimas da violação do direito à integridade psíquica e moral ${ }^{34}$.

O Brasil foi, então, condenado a investigar, julgar e, se possível, punir os responsáveis pelos crimes cometidos na Favela Nova Brasília. Além disso, seguindo o sistema adotado na sentença do caso da Guerrilha do Araguaia, o Brasil devia implementar rapidamente um programa obrigatório e permanente de formação de policiais civis e militares do Rio de Janeiro, assim como os agentes públicos de saúde, para o adequado atendimento às vítimas de estupro. Por fim, determinou-se a uniformização do conceito de morte decorrente de intervenção policial, devendo ser suprimida a possibilidade de execuções arbitrárias sob a forma de "autos de resistência" (CtIDH, 2017).

34 Artigo 5 da $\mathrm{CADH}$. 
9 POVO INDÍGENA XUCURU E SEUS MEMBROS VS. BRASIL (2018)

6.200 pessoas, distribuídas em diversas comunidades, localizadas majoritariamente em Pesqueira/PE, formam o Povo Indígena Xucuru. Historicamente, esse povo tem lutado por direitos territoriais, o que significa, no Brasil, a demarcação de suas terras tradicionais (VALENTE, 2018). A partir de 1996, terceiros interessados puderam impugnar demarcações de terras indígenas em defesa de seu direito de propriedade privada. Em 2001, homologou-se a demarcação da terra indígena Xucuru. Contudo, esse ato foi objeto de centenas de questionamentos, que foram aceitos pelo Poder Judiciário. Em 2014, transitou em julgado decisão judicial em favor dos ocupantes não indígenas, o que foi objeto de ação rescisória pela Fundação Nacional do Índio (FUNAI).

Em 2002, organizações não governamentais encaminharam uma petição à CIDH relatando a demora do Brasil em concluir o processo de reconhecimento, titulação, delimitação, demarcação e desintrusão ${ }^{35}$ da terra indígena Xucuru, o que significava a violação do direito de propriedade ${ }^{36}$ (PEREIRA et al., [s.d]). Sobre o direito de propriedade coletiva, a CtIDH tem reconhecido o vínculo substancial entre os povos indígenas e as terras tradicionalmente ocupadas. Trata-se da proteção internacional da dimensão identitária dos indivíduos como membros de uma coletividade, que só se reconhece por estar enraizada em um determinado espaço geográfico. Reconhece-se assim a importância da posse das terras tradicionalmente ocupadas como condição da proteção de uma determinada cultura (BENEDETTO, 2017). No caso do Povo Indígena Xucuru, a discussão sobre a propriedade coletiva deu-se em dois eixos, quais sejam a falta da titulação e a falta de desintrusão. O primeiro eixo refere-se ao direito de propriedade, enquanto o segundo diz respeito ao direito a garantias judiciais $^{37}$ e proteção judicial ${ }^{38}$.

Diante disso, a CtIDH reconheceu que, no Brasil, em caso de conflito entre o direito à propriedade coletiva e o direito à propriedade privada, o direito interno dá prioridade ao primeiro em detrimento do segundo. Prevalece sempre o direito coletivo, mesmo em face de

35 Finalizada a demarcação, dá-se lugar à desintrusão, medida de efetivação da posse da terra indígena por um povo, que prevê a retirada de eventuais ocupantes não indígenas.

36 Artigo 21 da CADH.

37 Artigo 8 da $\mathrm{CADH}$.

38 Artigo 25 da CADH. 
terceiros de boa-fé. Desta forma, cabe à CtIDH, no caso concreto, declarar internacionalmente a existência de um direito já reconhecido internamente pelo Brasil (CARRA, 2017).

Em seguida, a CtIDH analisou a efetividade das medidas do Brasil para garantir o direito à propriedade coletiva das terras tradicionalmente ocupadas pelo povo indígena Xucuru, no âmbito do dever de diligência devida. Neste sentido, verificou-se que, apesar das centenas de impugnações, o Estado já deveria ter concluído o processo de demarcação e desintrusão da terra indígena Xucuru, sendo identificada, por conseguinte, a violação do direito a garantias judiciais e proteção judicial. Como, apesar de reconhecido pelo Brasil o direito de propriedade coletiva do povo indígena Xucuru sobre as terras tradicionalmente ocupadas, o Estado não garantiu o pleno exercício desse direito, a CtIDH constatou ter havido violação do disposto no artigo 21 da CADH. Diante disso, condenou-se o Brasil a fazê-lo, concluindo com diligência a desintrusão da terra indígena Xucuru, indenizando os terceiros de boa-fé por eventuais benfeitorias no imóvel (CtIDH, 2018a).

\section{CASO VLADIMIR HERZOG E OUTROS VS. BRASIL (2018)}

Em 24 de outubro de 1975, o jornalista Vladimir Herzog foi intimado a comparecer à sede do Departamento de Operações de Informações e Centro de Operações de Defesa Interna (DOI/CODI) de São Paulo, órgão vinculado ao II Exército ${ }^{39}$, localizado na Rua Tutoia, Bairro Paraíso (LIMA, 2018). No dia seguinte, Vladimir dirigiu-se voluntariamente ao DOI/CODI, chegando ali no início da manhã. $\mathrm{Na}$ tarde do mesmo dia, sob custódia do Estado, Vladimir morreu, enforcado com o cinto ${ }^{40}$ do macacão de presidiário, em suspensão incompleta, isto é, com os pés apoiados no chão. Segundo o Estado brasileiro, baseado em perícia, Vladimir havia se suicidado, o que foi questionado prontamente, com base em fotos e no depoimento de George Duque Estrada e Leandro Konder, presos no DOI/CODI. Marcas de tortura foram identificadas pelo comitê funerário judaico, responsável pela preparação do corpo para o sepultamento. Por esse motivo, Vladimir não foi enterrado na parte do cemitério destinada aos suicidas (BRASIL, 2007).

Em 1976, a família de Vladimir protocolou uma ação declaratória

39 Trata-se, desde 1985, do Comando Militar do Sudeste, sediado em São Paulo/SP.

40 Apesar de outras pessoas, que foram presas ali no mesmo período, afirmarem não existir tal peça em seus macacões. (BRASIL, 2007)

Veredas do Direito, Belo Horizonte, $\cdot$ v.15 $\cdot$ n.33 $\cdot$ p.13-50 $\cdot$ Setembro/Dezembro de 2018 
contra a União, requerendo o reconhecimento da prisão arbitrária, tortura e morte do jornalista e o pagamento de indenização. Corajosamente, em 1978, o juízo reconheceu a prisão arbitrária, tortura e assassinato de Vladimir por agentes do Estado. Inconformada, a União apresentou o recurso de apelação, que foi julgado, em 1983, tendo o Tribunal Federal de Recursos declarado haver obrigação do Estado em indenizar a família de Vladimir, mas que o pedido deveria ter sido feito em ação específica. Contra a decisão recursal, a União apresentou embargos infringentes, que foram negados, transitando em julgado a decisão declaratória em 1995.

Em 1992, a Revista "Isto É, Senhor!" publicou reportagem em que um oficial do DOI/CODI, Pedro Antonio Mira Grancieri, o "Capitão Ramiro", confirmava seu envolvimento na morte de Vladimir. Diante da notícia, o Ministério Público de São Paulo requereu à Polícia Civil a abertura de investigação, que foi rapidamente arquivada com base na Lei de Anistia, após Capitão Ramiro ter impetrado um habeas corpus junto ao Tribunal de Justiça de São Paulo (SANTOS, 2017). Em 1993, enquanto a União recorria da decisão declaratória de tortura e assassinato de Vladimir, o então Ministro da Justiça, Maurício Corrêa, assinou um relatório oficial, segundo o qual Vladimir havia se suicidado por enforcamento dentro da sela que ocupava no DOI/CODI (BRASIL, 2007). Com a promulgação da Lei 9.140/1995, o Brasil reconheceu sua responsabilidade pelo assassinato de opositores políticos entre 1961 e 1979.

Anos depois do fim da ditadura ${ }^{41}$, diante do reconhecimento da jurisdição da CtIDH e do Tribunal Penal Internacional (TPI ${ }^{42}$ ) pelo Brasil, consolidado o entendimento internacional sobre a impossibilidade de prescrição e anistia de crimes contra a humanidade, o MPF passou a investigar fatos relacionados à repressão de opositores da ditadura. Em 2008, o MPF pretendeu iniciar a responsabilização dos assassinos de Vladimir. Contudo, discordâncias internas levaram o MPF a pedir, no ano seguinte, o arquivamento do feito, o que foi deferido pelo juízo federal, que identificou a existência de coisa julgada, inexistência do tipo penal sobre crime contra a humanidade e prescrição dos tipos penais aplicáveis. Ainda em 2009, chegou à CIDH uma petição sobre violações de direitos

41 Para alguns, a Ditadura Militar chegou ao fim em 1985, quando se elegeu indiretamente um civil, Tancredo Neves, para presidente. Outros sustentam que a Ditadura Civil-Militar terminou apenas com a promulgação da Constituição de 1988 .

42 O Brasil depositou o instrumento de ratificação do Estatuto de Roma do TPI em 20 de junho de 2002, passando a vigorar, para o País, em $1^{\circ}$ de setembro de 2002. Por meio da Emenda Constitucional 45/2004, a Constituição passou a contar com o artigo $5^{\circ}, \S 4^{\circ}$ com a seguinte redação: "O Brasil se submete à jurisdição de Tribunal Penal Internacional a cuja criação tenha manifestado adesão." 
humanos relacionada à morte de Vladimir (SANTOS, 2017).

Em 2011, instituiu-se internamente a Comissão Nacional da Verdade (CNV), que dedicou especial atenção à morte de Vladimir. Um importante desdobramento do trabalho da CNV foi a requisição à Justiça da retificação do registro do óbito de Vladimir, o que foi deferido, passando a constar como causa mortis as lesões e maus-tratos sofridos nas dependências do DOI/CODI, ao invés da mera menção à asfixia mecânica por enforcamento (BORGES; BRITTO, 2012). Em 2014, peritos da CNV elaboraram um laudo sobre a morte de Vladimir, demonstrando ter a vítima sido estrangulada no DOI/CODI. A novidade refere-se à constatação pela CNV de que, pela sistematicidade das graves violações de direitos humanos cometidas contra a população civil, houve a prática de crimes contra a humanidade, que não são passíveis de prescrição ou anistia e que fazem parte das hipóteses de competência material do TPI.

Em 2015, a família de Vladimir recebeu a certidão do registro retificado de óbito (BORGES, 2013). Neste ano, a CIDH recomendou ao Brasil determinar a responsabilidade criminal pela prisão arbitrária, tortura e assassinato de Vladimir, que são crimes contra a humanidade e, portanto, inanistiáveis e imprescritíveis. Além disso, deveria o Brasil indenizar os familiares de Vladimir por danos materiais e morais. Contudo, o Brasil não seguiu as recomendações, o que implicou a interposição da ação junto à CtIDH (SANTOS, 2017).

Diante do caso, a CtIDH analisou a responsabilidade do Estado com base nas obrigações derivadas da CADH e da CIPPT, relativamente à falta de investigação, julgamento e eventual punição dos torturadores e assassinos de Vladimir. Como o Brasil já havia reconhecido, por meio da Lei 9.140/1995, sua responsabilidade por esses fatos, a discussão restringiase à natureza jurídica dos crimes e a possibilidade de responsabilização dos autores, tendo em vista a Lei de Anistia. Além disso, analisou-se, também, a eventual violação do direito à verdade, em virtude da falsa versão da morte, da ausência de apresentação de documentos e da consequente falta de identificação dos responsáveis pelos crimes. Por fim, examinou-se a alegação de violação do direito à integridade pessoal dos familiares de Vladimir.

A CtIDH decidiu que, no momento da ocorrência dos fatos, a proibição de tortura, execução arbitrária e desaparecimento forçado já havia sido aceita e reconhecida como jus cogens, o que impunha ao Brasil a obrigação de investigar, julgar e punir os responsáveis pela 
tortura e assassinato de Vladimir, sendo nulas as disposições normativas de anistia ou perdão dos autores dos crimes. Na condenação, destaca-se a ordem de reiniciar a investigação para julgamento e responsabilização dos torturadores e assassinos de Vladimir, devendo reconhecer o Brasil a imprescritibilidade dos crimes contra a humanidade.

Visto ter o Brasil se mantido inerte desde 1975, apesar das inúmeras demandas em contrário, a CtIDH constatou que o Estado tem violado continuamente o dever de diligência devida quanto à investigação, julgamento e punição, assim como o direito à verdade. Uma vez que o Estado divulgou insistentemente a falsa versão de suicídio, esse fato causou dano à integridade pessoal de familiares de Vladimir, que também foram consideradas vítimas da violação do direito a garantias judiciais e proteção judicial (CtIDH, 2018b).

\section{O BRASIL COMO RÉU CONDENADO}

Uma vez condenado, o Brasil é obrigado ${ }^{43}$ a cumprir as sentenças da CtIDH. Nos últimos vinte anos, desde o reconhecimento da jurisdição contenciosa da CtIDH, o Brasil foi réu condenado em oito casos ${ }^{44}$. Quando a condenação determina o pagamento de indenização, o Estado tem cumprido a obrigação sem grandes problemas, como são exemplos os casos de Damião e Sétimo ${ }^{45}$ (LOUREIRO, 2008). O Brasil, inclusive, tem destinado, desde 2004, uma parte de seu orçamento ao pagamento de indenizações por descumprimento do direito internacional dos direitos humanos (CICCO FILHO; VELLOSO; ROCHA, 2014).

Os desafios acerca do cumprimento de sentença da CtIDH pelo Brasil referem-se à admissão da prescrição, anistia e coisa julgada, o que tem sido base para o descumprimento das decisões. No caso, por exemplo, do povo indígena Xucuru, uma ação de reintegração de posse de uma área de 300 hectares, localizada na terra indígena Xucuru, interposta por ocupante não indígena, foi julgada internamente procedente, transitando em julgado antes da leitura da decisão internacional (CtIDH, 2018a). Tornase importante discutir acerca dos efeitos da coisa julgada interna em favor de proprietário particular em conflito com a coisa julgada internacional em favor de proprietários coletivos.

Para a CtIDH, o princípio da coisa julgada não é absoluto, sendo 43 Artigo 68 da CADH.

44 A única absolvição foi no Caso Nogueira de Carvalho vs. Brasil.

45 Apesar dos pagamentos terem sido efetuados fora do prazo de um ano estipulado pela CtIDH. 
possível seu afastamento, quando demonstrado que o julgamento não foi independente e imparcial, havendo, assim, a coisa julgada "aparente" (BÁEZ; PARRÓN, 2015) ou "fraudulenta" (VERA, 2012). Quando se demonstra que o órgão jurisdicional interno atuou sem interesse de responsabilizar, a coisa julgada não deve produzir efeitos. Caso contrário, está-se diante do vedado bis in idem ${ }^{46}$. No caso do povo indígena Xucuru, a princípio, há conflito de coisa julgada interna e internacional, em que direitos de propriedade coletiva são inconciliáveis com a propriedade privada. Não se discute a imparcialidade do órgão jurisdicional interno para reexaminar a questão, como acontece normalmente com a obrigação internacional de investigar, julgar e punir, em que a coisa julgada pode ser suscitada. Trata-se, ao contrário, de solucionar um conflito de normas.

Visto ter o Brasil ratificado a CADH e reconhecido a jurisdição contenciosa da CtIDH, o princípio do pacta sunt servanda ${ }^{47}$ obriga o Estado a cumprir integralmente a sentença proferida em caso em que seja parte ${ }^{48}$. Logo, há a obrigação de, uma vez sendo o Estado parte do sistema interamericano de direitos humanos, os juízes nacionais aplicarem o direito interno, sem violar o direito internacional dos direitos humanos, realizando o controle concentrado de convencionalidade das leis. Quando de sua atuação, os juízes brasileiros devem assim estar em consonância com a CtIDH, intérprete última da $\mathrm{CADH}^{49}$. Neste sentido, sustenta-se não ser possível o Brasil alegar a existência de coisa julgada interna para descumprir a decisão da CtIDH, no caso do povo indígena Xucuru.

Outro grande desafio do Brasil refere-se justamente à obrigação de investigar, julgar e punir os autores das violações de direitos humanos, tendo em vista os institutos da prescrição e anistia (CANÇADO TRINDADE; ROBLES, 2004). No caso de Damião, por exemplo, cinco réus da ação penal foram condenados, em 2009, pelo crime qualificado de maus-tratos. Três anos depois, o Tribunal de Justiça do Ceará julgou procedente o recurso apresentado, reconhecendo a prescrição da pretensão punitiva do Estado (LIMA; PONTES, 2015). No Caso Escher e outros vs. Brasil, a sentença foi remetida à Procuradoria-Geral de Justiça do Paraná, para cumprir a obrigação de investigar os fatos relativos às interceptações 46 Artigo 8.4 da CADH.

47 CtIDH. Caso Trabalhadores Cesados del Congreso (Aguado Alfaro y otros) vs. Perú. Sentencia de 24 de noviembre de 2006 (excepciones preliminares, fondo, reparaciones y costas).

48 CtIDH. Opinião Consultiva (OC) 14/94, de 9 de dezembro de 1994, sobre a responsabilidade internacional por expedição e aplicação de leis de violação da Convenção Americana (artigos 1 e 2).

49 CtIDH. Caso Almonacid Arellano e outros vs. Chile. Sentença de 26 de setembro de 2006 (exceções preliminares, mérito, reparações e custas), § 124 . 
ilícitas. Porém, constatou-se ser juridicamente impossível a investigação, por conta da prescrição (PEREIRA, 2013).

Apesar da frequente oposição dos peticionários e da própria CIDH, a CtIDH tem reconhecido a prescrição em relação a violações não graves de direitos humanos. Nesse sentido, sobre o cumprimento da sentença do caso de Sétimo, o Brasil informou que, no âmbito administrativo, a Corregedoria-Geral de Polícia havia solicitado o arquivamento do processo por ausência de prova de autoria, o que foi aceito pela CtIDH (CEIA, 2013). No que concerne, por sua vez, à responsabilidade criminal, o Superior Tribunal de Justiça manteve, em 2016, quando do julgamento do Recurso Especial 1351177, a decisão de arquivamento do inquérito que visava investigar o crime (GARCIA, 2016). A pouco tempo de haver a prescrição da pretensão punitiva em face do homicídio de Sétimo (CtIDH, 2009b), organizações não governamentais têm se mobilizado para que a CtIDH não reconheça o cumprimento da sentença pelo Brasil sob essa justificativa (BORGES, 2018).

A mesma indefinição existe em relação ao cumprimento da sentença no caso da Favela Nova Brasília. A CtIDH identificou encontrarse pendente a condução eficaz de investigação, julgamento e punição dos responsáveis pelas chacinas. Como elas ocorreram em 1994 e 1995, haveria a prescrição, nos termos do direito processual penal brasileiro. Contudo, diferentemente do homicídio de Sétimo, que não foi identificado pela CtIDH como grave violação de direito humano, as chacinas na Favela Nova Brasília foram tratadas como execuções extrajudiciais, que, por sua gravidade, afastam a aplicação da prescrição ${ }^{50}$ (GROSSMAN, 2008). Apesar de não haver discussão acerca de imprescritibilidade de graves violações de direitos humanos, o Brasil tem reiterado, em manifestações do Ministério Público e do Poder Judiciário, inexistir possibilidade jurídica de responsabilização dos autores dos crimes cometidos na Favela Nova Brasília (CtIDH, 2017), o que configura uma nova violação do direito internacional. Neste caso, a CtIDH indica o caso à Assembleia Geral da OEA em que o Estado não tenha dado cumprimento à sentença $a^{51}$.

A prática da escravidão é outra grave violação de direitos humanos que impede a prescrição. Pelo menos desde 1945, com o Estatuto do Tribunal Militar Internacional de Nuremberg, a escravidão é considerada crime contra a humanidade. Já o Tribunal Penal Internacional ad hoc para

50 CtIDH. Caso Barrios Altos vs. Peru. Sentença de 14 de março de 2001 (mérito), $\S 41$.

51 Artigo 65 da CADH. 
a ex-Iugoslávia considerou, em 1992, que as formas contemporâneas de escravidão faziam parte da tipificação de crime contra a humanidade. A obrigação de reiniciar as investigações ou ações penais acerca dos fatos constatados na Fazenda Brasil Verde faz parte da sentença da CtIDH, que determinou que o Brasil tome as medidas necessárias para que a prescrição não seja aplicada à escravidão e suas formas análogas, que são crimes contra a humanidade. Por conta disso, o Brasil não pode alegar a existência de prescrição ou do princípio de non bis in idem como desculpa para descumprir a sentença (CtIDH, 2018b, § 232).

Também foram considerados pela CtIDH graves violações de direitos humanos os crimes cometidos por agentes do Estado contra membros da Guerrilha do Araguaia, impassíveis de anistia e prescrição. Com base nisso, órgãos de Estado, notadamente o MPF, têm exigido a responsabilização dos autores de violações de direitos humanos ocorridas durante a ditadura. Contudo, por conta da anistia e prescrição, o Poder Judiciário tem se caracterizado por inviabilizar o cumprimento da sentença da $\mathrm{CtIDH}^{52}$. De fato, quanto à responsabilização penal, mesmo em ações de desaparecimento forçado de pessoas, visto como crime continuado de lesahumanidade, o Brasil continua a impedir a investigação e o julgamento dos acusados (RABELO, 2015). Das 36 ações $^{53}$ que o MPF ajuizou nos últimos anos, em todo o país, contra agentes da repressão envolvidos em assassinatos de dissidentes políticos, somente duas estão em andamento (MPF, 2018).

Sobre a vedada anistia de crimes contra a humanidade, destacase o julgamento pelo STF, em 2010, da Arguição de Descumprimento de Preceito Fundamental 153 (SANTOS, 2011). Por maioria ${ }^{54}$, o tribunal considerou ser a Lei da Anistia um importante movimento político de conciliação nacional, que significava o esquecimento de todos os crimes praticados por agentes da ditadura (BARROZO; SILVA; PALUMA, 2014). Ora, o sistema jurídico de direitos humanos funda-se no princípio da justiça, verdade e memória, o que se opõe diretamente a qualquer proposta

52 Parece que isso começa pouco a pouco a mudar. Em 22 de agosto de 2018, noticiou-se que o Tribunal Regional Federal da $3^{\text {a }}$ Região decidiu, por três votos a dois, ser imprescritível a reparação por danos causados por tortura durante a ditadura. (NUNES, 2018)

53 Há que se mencionar, por questão de memória da Guerrilha do Araguaia, as vãs tentativas de responsabilização penal de Sebastião Rodrigues de Moura, o "Major Curió", por sequestro qualificado, maus-tratos e ocultação de cadáver; o Tenente-Coronel Lício Augusto Maciel, por sequestro qualificado, maus tratos e homicídio (GRABOIS, 2018)

54 Formaram a maioria os ministros Cármen Lúcia, Ellen Gracie, Eros Grau (relator), Gilmar Mendes, Marco Aurélio, Celso de Mello e Cezar Peluso. Já os ministros Ayres Britto e Ricardo Lewandowski defenderam que certos crimes são absolutamente incompatíveis com a noção de criminalidade política. 
de esquecimento. Além disso, para tentar justificar o posicionamento do STF, afirmou-se que a Lei de Anistia não poderia ser confundida com a autoanistia $^{55}$ vedada pelo direito internacional (UNNEBERG; MELO, 2014). Ora, não se faz essa diferenciação conceitual para permitir a anistia de crimes contra a humanidade. Mesmo se se fizesse, por questão de lógica, o Estado conceder anistia a seus agentes significa a autoanistia.

Diante da sentença da CtIDH sobre a Guerrilha do Araguaia, o Ministro do STF, Marco Aurélio, chegou a posicionar-se publicamente, defendendo não apenas o monismo nacionalista, isto é, afirmando que, em caso de conflito normativo, o direito interno sobrepõe-se ao direito internacional, mas tratando a sentença da CtIDH como decisão política (GOMES, 2011). Erro crasso! Como está consolidado na jurisprudência ${ }^{56}$ internacional, o desaparecimento forçado de pessoas é violação de jus cogens (CtIDH, 2010, § 105). Logo, são nulas as disposições normativas em conflito, sejam convencionais, consuetudinárias, sejam internas. Por conta disso, a CtIDH determinou que as disposições da Lei da Anistia, que implicam a impunidade de responsáveis por graves violações de direitos humanos, "carecem de efeitos jurídicos" (CtIDH, 2010, § 174). Em mais uma tentativa, o MPF abriu uma nova investigação visando à responsabilidade criminal de agentes da ditadura pela morte de Vladimir, procurando dar cumprimento à sentença da $\mathrm{CtIDH}$, tendo em vista que se considerou que sua tortura e morte constituem crimes contra a humanidade (CtIDH, 2018b).

\section{CONCLUSÃO}

Há vinte anos, o Brasil reconheceu soberanamente a jurisdição contenciosa da CtIDH. Uma vez praticado o ato, não se admite limitações não previstas no artigo 62 da $\mathrm{CADH}$, especialmente de caráter interno (GONZÁLEZ, 2006). Em virtude do reconhecimento, desde 1998, a CtIDH tem competência para julgar o mérito de casos que envolvam acusação de violação de dispositivos da CADH pelo Brasil, que é Estado-parte desde 1992. Uma vez julgado um caso por sentença da CtIDH, se houver

55 No Caso "Almonacid Arrellano e outros vs. Chile", a CtIDH determinou que leis de autoanistia não podem representar obstáculo à investigação, julgamento e punição dos responsáveis pelas atrocidades cometidas. (FERREIRA JÚNIOR, 2013)

56 CtIDH. Caso Goiburú e outros vs. Paraguai. Sentença de 22 de setembro de 2006 (mérito, reparações e custas), § 84; Caso Chitay Nech e outros vs. Guatemala. Sentença de 25 de maio de 2010, § 86; Caso Ibsen Cárdenas y Ibsen Peña vs. Bolívia. Sentencia de 1 de septiembre de 2010 (fondo, reparaciones y costas), $\S 61$. 
condenação, o Brasil deve cumprir a decisão integralmente, nos termos do artigo 68 da CADH. A sentença da CtIDH é, portanto, vinculante para as partes do caso.

A CtIDH, nos últimos vinte anos, julgou nove casos em que o Brasil foi réu. A temática desses casos dá uma visão panorâmica dos grandes dramas nacionais. Pode-se dividir essa temática em quatro grandes eixos: violência policial, trabalho escravo, questão fundiária e violência médica.

Os casos de violência policial são aqueles em que agentes de segurança pública utilizam excessivamente a força, segundo parâmetros internacionais, mesmo que, eventualmente, estejam amparados por norma jurídica interna. Isso significa que a violência policial pode ser nacionalmente lícita, mas internacionalmente ilícita, o que põe em discussão sua legitimidade interna. Os casos decididos pela $\mathrm{CtIDH}$, relacionados à violência policial no Brasil, são aqueles fundados no assassinato de Gilson por grupo de extermínio, nas chacinas da Favela Nova Brasília, nos desaparecimentos forçados de pessoas associadas à Guerrilha do Araguaia e no assassinato de Vladimir.

O caso relativo ao trabalho escravo refere-se aos trabalhadores da Fazenda Brasil Verde. A escravidão é uma cicatriz profunda na sociedade brasileira. Entre os séculos XVI e XIX, foram trazidos à força, para cá, milhões de africanos, para trabalharem como escravos em grandes propriedades rurais. Em 1888, a escravidão foi abolida por lei ${ }^{57}$ no Brasil, mas isso não impediu que a exploração do trabalho escravo permanecesse; infelizmente, uma característica marcante do processo produtivo nacional durante o século XX.

Relacionada à questão do trabalho escravo, uma vez que a escravidão é tradicionalmente o modelo de exploração da força de trabalho alheia em contexto da produção rural, encontra-se a questão fundiária. Desde o período colonial, o Brasil adotou um modelo de concentração de terras, cuja desconstrução implica uma reforma agrária eternamente adiada pelos agentes políticos estatais. Como consequência, a desigualdade na distribuição de terras, acompanhada da falta de políticas públicas de equilíbrio socioeconômico no meio rural, faz com que a disputa fundiária seja acompanhada de conflito e violência. Movimentos sociais, comunidades tradicionais, quilombolas e povos indígenas têm pressionado o Estado brasileiro para garantir o direito de acesso à terra. Nesse contexto, 57 Lei 3.353, de 13 de maio de 1888, que declara extinta a escravidão no Brasil. 
os casos de Sétimo e dos diretores da COANA referem-se especificamente à criminalização de movimentos sociais como o MST, enquanto o caso do povo indígena Xucuru retrata a longa luta dos indígenas pela posse de suas terras tradicionais.

Sobre a violência médica, o Brasil foi condenado no caso de Damião, morto em um hospital de tratamento de doenças mentais. A violência médica costuma ser uma agressão física ou psíquica, quase sempre intencional, praticada em ambientes hospitalares, que se justifica perversamente pelo próprio bem do paciente. Não é tema novo, pois se questiona há tempo as implicações do biopoder sobre os destinos dos seres humanos (FOUCAULT, 2014).

Nos últimos vinte anos, dos nove casos, o Brasil foi réu condenado pela CtIDH em oito. Logo, deve o Estado cumprir integralmente o disposto na sentença. No que concerne à condenação no caso do povo indígena Xucuru, a coisa julgada interna, que garante direitos de propriedade particular a ocupantes não indígenas, não pode impedir o cumprimento da sentença internacional, pois não se trata de ordem para novo julgamento interno, o que poderia dar ensejo a essa discussão. Trata-se de solucionar um conflito, mas, o conflito de normas, cuja solução segue o monismo internacionalista, por conta do disposto no artigo 68 da $\mathrm{CADH}$, em vigor para o Brasil desde 1992. Ademais, a própria CtIDH determinou que terceiros de boa-fé devem ser indenizados pelas benfeitorias feitas na terra indígena Xucuru. Logo, reconhecidos os direitos dos ocupantes não indígenas, não é possível sua permanência naquele espaço, mas lhe é garantida a reparação pelo trabalho ali realizado durante o processo de demarcação e desintrusão. As dificuldades de cumprimento, neste caso, são menores do que as de outros.

De fato, tem havido, de maneira geral, grandes dificuldades em cumprir sentenças da CtIDH, por conta da admissão de prescrição e anistia, quando se trata da obrigação internacional de investigar, julgar e punir, no âmbito interno, os autores de graves violações de direitos humanos. Tais dificuldades ocorrem apesar de a CtIDH já ter consolidado o entendimento de que a prescrição e a anistia não podem ser obstáculo à identificação e sanção dos responsáveis por graves violações de direitos humanos, como o são os fatos relacionados à Guerrilha do Araguaia, aos trabalhadores da Fazenda Brasil Verde, às chacinas da Favela Nova Brasília e à morte de Vladimir Herzog. Logo, reconhecer a prescrição em relação às execuções extrajudiciais e à exploração de trabalho análogo à escravidão é uma 
violação em si do direito internacional. Reconhecer a anistia em relação aos desaparecimentos forçados, qualificados como terrorismo de Estado ${ }^{58}$, é uma ofensa aos parâmetros mais elementares da justiça internacional, o que mantém o Brasil na condição de contínuo violador de direitos humanos e acobertador de criminosos contra a humanidade. Que o TPI, um dia, os julgue!

\section{REFERÊNCIAS}

BÁEZ, Ana Alejandra; PARRÓN, Mario Gustavo. Doble enjuiciamientos y Derechos Humanos en el Perú contemporáneo: Estudio de casos. Revista Digital de la Escuela de Historia, Facultad de Humanidades y Artes, Universidad Nacional de Rosario, vol. 7, n. 15, 2015, [s.p.]

BARROZO, Rebecca Paradellas; SILVA, Stevan Bernardino; PALUMA, Thiago. O Brasil e o Sistema Interamericano de Direitos Humanos: De Nogueira de Carvalho à Guerrilha do Araguaia. Revista Jurídica UNICURITIBA, vol. 4, n. 37, 2014, pp. 335-358.

BASTOS JR, Luiz Magno Pinto; CUNHA, Amanda Guimarães da. A (im) prescritibilidade dos crimes de lesa humanidade: precedentes históricos e aplicação na jurisprudência da Corte Interamericana de Direitos Humanos. Revista de Direitos Humanos em Perspectiva, vol. 3, n. 1, 2017, pp. 103-123.

BENEDETTO, Saverio di. La funzione ecologica della proprietà collettiva sulle terre ancestrali: un nuovo modello di rapporto tra diritti umani e tutela dell'ambiente?. Veredas do Direito, vol. 14, n. 30, 2017, pp. 11-37.

BERNARDES, Edilene Mendonça; VENTURA, Carla Aparecida Arena. Direitos Humanos no Brasil: uma análise da demanda brasileira junto à Comissão e à Corte Interamericana de Direitos Humanos no período de 2003 a 2010. Direito, Estado e Sociedade, n. 40, 2012, pp. 65-90.

BORGES, Bruna. Família de Herzog recebe novo atestado de óbito; veja certidão. Folha de S. Paulo, 15 mar. 2013, Poder, https://www1.folha.uol.

58 CtIDH. Caso Gelman vs. Uruguay. Sentencia de 24 de febrero de 2011 (fondo y reparaciones), $\S$ 99. 
com.br/poder/2013/03/1246463-familia-recebe-novo-atestado-de-obitode-herzog.shtml

BORGES, Bruna; BRITTO, Patrícia. Justiça mantém nova versão do atestado de óbito de Vladimir Herzog. Folha de S. Paulo, 13 dez. 2012, Poder, https://www1.folha.uol.com.br/poder/2012/12/1200776-justicamantem-nova-versao-do-atestado-de-obito-de-vladimir-herzog.shtml

BORGES, Lizely. Organizações de direitos humanos solicitam audiência à Corte Interamericana de Direitos Humanos sobre o assassinato do sem terra Sétimo Garibaldi. Terra de Direitos, 17 abr. 2018, https:// terradedireitos.org.br/noticias/noticias/organizacoes-de-direitos-humanossolicitam-audiencia-a-corte-interamericana-de-direitos-humanos-sobre-oassassinato-do-sem-terra-setimo-garibaldi/22800

BRASIL. Direito à verdade e à memória: Comissão Especial sobre Mortos e Desaparecidos Políticos. Brasília: Secretaria Especial dos Direitos Humanos, 2007.

CANÇADO TRINDADE, Antonio Augusto; ROBLES, Manuel E. Ventura. El Futuro de la Corte Interamericana de Derechos Humanos.

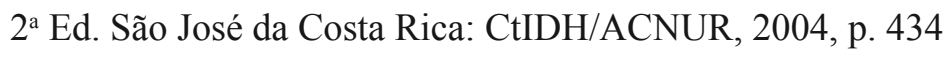

CANÇADO TRINDADE, Antônio Augusto. O Direito Internacional em um mundo em transformação. Rio de Janeiro: Renovar, 2002

CARRA, César Augusto. Reflexão dialética acerca do caso n. 12.728 Povo Indígena Xucuru. Revista da AGU, vol. 16, n. 2, 2017, pp. 87-104.

CEIA, Eleonora Mesquita. A Jurisprudência da Corte Interamericana de Direitos Humanos e o Desenvolvimento da Proteção dos Direitos Humanos no Brasil. R. EMERJ, vol. 16, n. 61, 2013, pp. 113-152.

CELA, Vânia Vaz Barbosa; SILVA, Clara Cavalcante. Corte Interamericana de Direitos Humanos. Caso A: Favela Nova Brasília Vs. República Federativa do Brasil. Caso B: Vladimir Herzog Vs. República Federativa do Brasil. Guia de Estudos apresentado ao Projeto de Extensão e Pesquisa UNISIM-RN, 2017, 57 p. 
CICCO FILHO, Alceu José; VELLOSO, Ana Flávia Penna; ROCHA, Maria Elizabeth Guimarães Teixeira. Direito Internacional na Constituição: Estudos em homenagem a Francisco Rezek. São Paulo: Saraiva, 2014.

CtIDH. Caso do Povo Indígena Xucuru e seus membros vs. Brasil. Sentença de 5 de fevereiro de 2018a (exceções preliminares, mérito, reparações e custas). Resumo oficial.

CtIDH. Caso Escher e outros vs. Brasil. Sentença de 6 de julho de 2009a (exceções preliminares, mérito, reparações e custas).

CtIDH. Caso Favela Nova Brasília vs. Brasil. Sentença de 16 de fevereiro de 2017 (exceções preliminares, mérito, reparações e custas). Resumo oficial.

CtIDH. Caso Garibaldi vs. Brasil. Sentença de 23 de setembro de 2009b (exceções preliminares, mérito, reparações e custas).

CtIDH. Caso Gomes Lund e outros ("Guerrilha do Araguaia") vs. Brasil. Sentença de 24 de novembro de 2010 (exceções preliminares, mérito, reparações e custas).

CtIDH. Caso Herzog e outros vs. Brasil. Sentença de 15 de março de 2018b (exceções preliminares, mérito, reparações e custas).

CtIDH. Caso Nogueira de Carvalho e outro vs. Brasil. Sentença de 28 de novembro de 2006 b.

CtIDH. Caso Trabalhadores da Fazenda Brasil Verde vs. Brasil. Sentença de 20 de outubro de 2016 (exceções preliminares, mérito, reparações e custas).

CtIDH. Caso Ximenes Lopes versus Brasil. Sentença de 4 de julho de 2006a.

DUARTE, Lorena Paula José. O Caso Fazenda Brasil Verde: Capital, 
Trabalho, Dependência e Direito no Sistema Interamericano de Direitos Humanos. Dissertação de Mestrado sob orientação da Professora Dra. Letícia Albuquerque. Florianópolis: UFSC, 2017, 174 p.

FERREIRA JÚNIOR, José Carlos Macedo de Pinto. A responsabilidade do Brasil pelos crimes contra a humanidade: análise do julgamento "Gomes Lund e outros". Revista Prolegómenos - Derechos y Valores, vol. XVI, n. 32, 2013, pp. 69-85.

FOUCAULT, Michel. Microfísica do poder. $28^{\mathrm{a}}$ Ed. São Paulo: Paz e Terra, 2014.

GARCIA, Luciana Silva. O Caso Sétimo Garibaldi e as contradições do sistema de justiça frente a decisões do Sistema Interamericano de Direitos Humanos. Revista de Direitos Humanos em Perspectiva, vol. 2, n. 1, 2016, pp. 192-211.

GOMES, Luiz Flávio. Crimes da ditadura militar e o "Caso Araguaia": aplicação do direito internacional, dos direitos humanos pelos juízes e tribunais brasileiros. In: GOMES, Luiz Flávio; MAZZUOLI, Valerio de Oliveira. Crimes da ditadura militar: uma análise à luz da jurisprudência atual da Corte Interamericana de Direitos Humanos: Argentina, Brasil, Chile, Uruguai. São Paulo: Revista dos Tribunais, 2011, pp. 73-86.

GONZÁLEZ, Boris Barrios. La cosa juzgada nacional y el cumplimiento y ejecución de las sentencias de la Corte Interamericana de los Derechos Humanos por los Estados parte. Estudios Constitucionales, Universidad de Talca, año 4, n. 2, 2006, pp. 363-392.

GRABOIS, Victória. A Guerrilha do Araguaia e a sentença da Corte Interamericana de Direitos Humanos. Transversos: Revista de História, n. 12,2018 , pp. 221-234.

GROSSMAN, Claudio. The Inter-American System of Human Rights: Challenges for the Future. Indiana Law Journal, vol. 83, 2008, pp. 1.2681.282 . 
JUSTAMAND, Michel; MECHI, Patricia Sposito. Guerrilha do Araguaia: Arqueologia, História e Direitos Humanos. Revista Latino-Americana de Arqueologia Histórica, vol. 8, n. 2, 2014, pp. 75-90.

LEMES, Fernanda Siqueira; CEOLIN, Raquel Frescura. A proteção dos direitos humanos para além do Estado a partir do controle de convencionalidade: a experiência brasileira perante o diálogo com a Corte Interamericana. Anais do $\mathbf{4}^{\circ}$ Congresso Internacional de Direito e Contemporaneidade: mídias e direitos da sociedade em rede. Fortaleza: CONPEDI, 2010, pp. 7.479-7.495.

LIMA, Alcides Saldanha. A Convenção Americana sobre Direitos Humanos e a razoável duração do processo - reflexões a partir de dois precedentes da Corte Interamericana de Direitos Humanos: Ximenes Lopes e Nogueira de Carvalho (versus Brasil). Anais XIX Encontro Nacional do CONPEDI. Santa Maria: Universidade Federal de Santa Maria, 2017, pp. 1-14.

LIMA, Aluísio Ferreira de; PONTES, Maria Vânia Abreu. O Caso Damião Ximenes Lopes e a primeira condenação internacional do Brasil na Corte Interamericana de Direitos Humanos. Cadernos Brasileiros de Saúde Mental, vol. 7, n. 16, 2015, pp. 1-13.

LIMA, Camila Montanha de. Vladimir Herzog, presente!. Justificando, 10 jul. 2018, http:/justificando.cartacapital.com.br/2018/07/10/vladimirherzog-presente/

LOUREIRO, Sílvia Maria da Silveira. Caso Ximenes Lopes versus Brasil: o cumprimento integral da sentença. Revista do Instituto Brasileiro de Direitos Humanos, vol. 8, n. 8, 2008, pp. 207-223.

MENEZES, Rafael Lessa Vieira de Sá. O Caso Favela Nova Brasília: rumo ao controle e à auditabilidade do uso excessivo da força policial? In: ALMEIDA, Eloísa Machado de et al. Direitos Humanos: Sistema Interamericano de Proteção dos Direitos Humanos. Cadernos da Defensoria Pública do Estado de São Paulo, n. 6, 2017, pp. 92-105.

MICHEL, Voltaire de Freitas; DEITOS, Marc Antoni. A admissibilidade 
de demandas territoriais indígenas na Comissão Interamericana de Direitos Humanos. Veredas do Direito, vol. 14, n. 28, 2017, pp. 73-92.

MPF. MPF instaura novo procedimento para investigar morte de Vladimir Herzog. Assessoria de Comunicação da Procuradoria da República no Estado de São Paulo, 6 ago. 2018, [s.p.]

NUNES, Carolina Luchina Giordani. O princípio da razoável duração do processo e seus critérios de definição no âmbito do Sistema Interamericano de Direitos Humanos: um estudo do Caso Damião Ximenes Lopes. Revista do CEJUR/TJSC: Prestação Jurisdicional, vol. V, n. 1, 2017, pp. 35-58.

NUNES, Wálter. TRF-3 decide que reparação por tortura no regime militar não prescreve. Folha de São Paulo, 22 ago. 2018, https://www1.folha.uol. com.br/poder/2018/08/trf-3-decide-que-reparacao-por-tortura-no-regimemilitar-nao-prescreve.shtml

OLIVEIRA, Marlus H. Arns de. Divulgação de conteúdo de interceptação telefônica ilegal e a condenação do Estado brasileiro pela Corte Interamericana de Direitos Humanos no denominado "Caso Escher". In: ROVER, Aires José; SIMÃO FILHO, Adalberto; PINHEIRO, Rosalice Fidalgo. Direito e novas tecnologias. Florianópolis: FUNJAB, 2013, pp. 213-233.

PEREIRA, Marcela da Fonseca et al. Amicus curiae como estratégia de protecao dos direitos humanos do Povo Xucuru. 70 anos: tempos transversos, Pró-Reitoria de Extensão e Cultura da UFPE, [s.d], 5 p.

PEREIRA, Taís Mariana Lima. O cumprimento das decisões da Corte Interamericana de Direitos Humanos pelo Brasil. EJJL, vol. 14, n. 2, 2013, pp. 315-348.

PIOVESAN, Flávia. Brasil e o Sistema Interamericano de Proteção dos Direitos Humanos: impacto, desafios e perspectivas. II Anuário Brasileiro de Direito Internacional, vol. 1, 2007, pp. 114-130.

PIOVESAN, Flávia Cristina; QUETES, Regeane Bransin; FERRAZ, Miriam Olivia Knopik. Violações aos direitos humanos dos trabalhadores 
e os sistemas regionais de proteção. EJJL, vol. 19, n. 1, 2018, pp. 87-112.

RABELO, Marcia. A Lei de Anistia Brasileira e o Caso da Guerrilha do Araguaia Diante das Decisões do Supremo Tribunal Federal e da Corte Internacional de Direitos Humanos. In: GARCIA, Valdinei Pereira. Temas Atuais de Direito Constitucional. São Paulo: LTR, 2015, pp. 123-135.

RAMOS, André de Carvalho. Análise crítica dos casos brasileiros Damião Ximenes Lopes e Gilson Nogueira de Carvalho da Corte Interamericana de Direitos Humanos. II Anuário Brasileiro de Direito Internacional, vol. 1, 2007, pp. 10-31.

RAMOS, André de Carvalho. Reflexões sobre as vitórias do caso Damião Ximenes. Consultor Jurídico, 8 set. 2006, https://www.conjur.com. br/2006-set-08/reflexoes_vitorias_damiao_ximenes

ROCHA, Cristiana Costa da. O caso "Trabalhadores da Fazenda Brasil Verde vs. Brasil": trajetórias de luta por justiça de trabalhadores escravizados. Revista do Arquivo Geral da Cidade do Rio de Janeiro, n. 11, 2016, pp. 357-374.

ROSATO, Cássia Maria; CORREIA, Ludmila Cerqueira. Caso Damião Ximenes Lopes: Mudanças e Desafios Após a Primeira Condenação do Brasil pela Corte Interamericana de Direitos Humanos. SUR - Revista Internacional de Direitos Humanos, vol. 8, n. 5, 2011, pp. 115-134.

SANTOS, Amanda Cataldode Souza Tilio dos. Um novo efeito "bumerangue": o Caso Vladimir Herzog e o Sistema Interamericano de Direitos Humanos. Lex Humana, vol. 9, n. 1, 2017, pp. 1-25.

SANTOS, Davi Hoerlle. CIDH vs. STF: O caso $\mathbf{n}^{0} 11.552$ (Guerrilha do Araguaia) em confronto com a ADPF no 153 (Lei de Anistia). Monografia sob orientação da Professora Christine Oliveira Peter da Silva. Brasília: UniCEUB, 2011, 68 p.

SCHENK, Leonardo Faria. Notas sobre o modus operandi das Cortes Europeia e Interamericana para a aferição das violações ao direito à razoável duração dos processos. Revista Eletrônica de Direito Processual, vol. XI, 2013, pp. 292-308. 
SILVA, Grazielly Soares da; MONT'ALVERNE, Tarin Cristino Frota. O dia em que uma favela se levantou contra o Brasil: análise do Caso Favela Nova Brasília na Corte Interamericana de Direitos Humanos. Encontros Universitários da UFC, vol. 2, 2017, p. 3.884.

UNNEBERG, Flávia Soares; MELO, Álisson José Maia. O Brasil e a Corte Interamericana de Direitos Humanos: as sentenças condenatórias e sua repercussão interna. Revista do Programa de Pós-Graduação em Direito da UFC, vol. 34, n. 1, 2014, pp. 65-80.

VALENTE, Jonas. Corte Interamericana responsabiliza Brasil por desrespeito a direitos indígenas. EBC, 15 mar. 2018, http://agenciabrasil. ebc.com.br/direitos-humanos/noticia/2018-03/corte-interamericanaresponsabiliza-brasil-por-desrespeitar

VERA, Oscar Parra. La jurisprudencia de la Corte Interamericana respecto a la lucha contra la impunidad: algunos avances y debates. Revista Jurídica de la Universidad de Palermo, año 13, n. 1, 2012, pp. 5-51.

VILLELA, Flávia. Corte Interamericana de Direitos Humanos condena Brasil por trabalho escravo. EBC, 16 dez. 2016, http://agenciabrasil. ebc.com.br/direitos-humanos/noticia/2016-12/corte-interamericana-dedireitos-humanos-condena-brasil-por

ZAVERUCHA, Jorge; LEITE, Rodrigo. A impunidade de agentes estatais nos casos julgados pela Corte Interamericana de Direitos Humanos. Rev. bras. segur. pública, vol. 10, n. 1, 2016, pp. 88-107.

\section{Como citar este artigo (ABNT):}

TOLEDO, André de Paiva; BIZAWU, Kiwonghi. O BRASIL EM SÃO JOSÉ DA COSTA RICA: 20 ANOS DE RECONHECIMENTO DA JURISDIÇÃO CONTENCIOSA DA CORTE INTERAMERICANA DE DIREITOS HUMANOS. Veredas do Direito, Belo Horizonte, v. 15, n. 33, p. 13-50, set./dez. 2018. Disponível em: <http://www.domhelder.edu.br/revista/index.php/veredas/ article/view/1384>. Acesso em: dia mês. ano.

Artigo recebido em: 21/09/2018. Artigo aceito em: 20/11/2018. 